\title{
The Case for Humanities Training: A Woman of Color Teaching Social Justice in a Predominantly White Institution
}

\author{
Ginger $\mathrm{Ko}^{1}$
}

This paper describes the experience of a woman of color teaching social justice at an institution with a predominantly white student body. Student aggressions against the teacher's embodiment in the classroom were disruptive to the class material, and compounded student resistance to social justice concepts. Enacting the tenets of feminist pedagogy in the classroom were at first largely unsuccessful, and an intermediate step of modeling critical thinking was needed to temper student inexperience with democratic citizenship in a learning environment. The arc of a semester-long journey with the class is documented, and the case made for humanities training to prepare students for a participatory and discursive style of learning that can enhance their college-level learning experiences. [Article copies available for a fee from The Transformative Studies Institute. E-mail address: journal@transformativestudies.org Website: http://www.transformativestudies.org (C2015 by The Transformative Studies Institute. All rights reserved.]

KEYWORDS: Feminist Pedagogy, Women of Color, Women Teachers, Humanities Training, Social Justice.

My entrance into instruction began as a graduate assistant at a tiny state university. I was thrown in head-first as teacher-of-record for a 20-student Composition and Rhetoric course, which served primarily as a freshman service course. The college campus is situated in the third most populous town in a state that is over $90 \%$ white, and most resident students come from smaller towns around the state. When I was receiving teacher training for my Composition and Rhetoric course, I was warned that many of my students would come from conservative backgrounds, and would resent and resist any intrusions that had the look or feel of "liberal ideology." My training prepared me to temper any politicized discussion topics with a redirection towards the content of the evidence, and the structure of the argument. This training, I realized, was suggested as a self-preserving measure, and was meant to insure against student resistance and, thus, obstacles to effective teaching.

\footnotetext{
${ }^{1}$ Ginger Ko received her MFA in Creative Writing, with a graduate minor in Gender \& Women's Studies, from the University of Wyoming. She is pursuing in Ph.D. in English Literature at the University of Georgia. Address correspondence to: Ginger Ko; e-mail: gingerko@gmail.com.
} 